Article

\title{
Drivers and Outcomes of Business Model Innovation-Micro, Small and Medium-Sized Enterprises Perspective
}

\author{
Andreja Pucihar *, Gregor Lenart, Mirjana Kljajić Borštnar, Doroteja Vidmar and Marjeta Marolt \\ Faculty of Organizational Sciences, University of Maribor, 4000 Kranj, Slovenia; \\ gregor.lenart@fov.uni-mb.si (G.L.); mirjana.kljajic@fov.uni-mb.si (M.K.B.); \\ doroteja.vidmar@fov.uni-mb.si (D.V.); marjeta.marolt@fov.uni-mb.si (M.M.) \\ * Correspondence: andreja.pucihar@fov.uni-mb.si; Tel.: +386-4-2374-218
}

Received: 30 November 2018; Accepted: 4 January 2019; Published: 11 January 2019

\begin{abstract}
Business model innovation (BMI) is one of the key activities, which has to be continuously undertaken in every enterprise to sustain competitiveness in today's digital economy. Although the interest in business models (BM) has risen significantly since the late 1990s, little is known about BMI practices in small- and medium-sized enterprises (SMEs), representing a majority of enterprises in the European market. Our study addresses this research gap and focuses on the investigation of drivers and outcomes of BMI in SMEs. A partial least squares path modeling (PLS-PM) method was used to empirically test the model using data collected in 2017 from 71 SMEs in Slovenia. Results have shown that the innovativeness of enterprises and their business environment has a positive impact on the level of BMI activities in the enterprises. However, this is not the case of fast developing and rapidly changing information technology. In addition, the results show that the level of BMI has a positive impact on BMI outcomes and further on overall business performance. The results contribute to the body of knowledge in the field of BMI activities in SMEs and offer useful insights to SMEs that intend to innovate their business model(s) and government to create a supportive environment.
\end{abstract}

Keywords: business model; business model innovation; drivers; innovation; business environment; information technology; outcomes; performance; SMEs

\section{Introduction}

Business models (BMs) and business model innovation (BMI) are increasingly gaining attention in both entrepreneurial practice and in research [1-4]. However, although the amount of literature increases, it seems that a sound theoretical foundation of BMs and the BMI concept is still missing $[5,6]$. Moreover, diverse, non-uniform research findings present a challenge and the need for further research [7]. In general, a BM describes business logic and reflects how an enterprise creates, delivers, and captures value [8,9]. This implies that the most important management activity is to have a clear vision about the enterprise's BM. Among other activities, this requires knowing customers' needs and expectations, how value can be best delivered, and how to engage with strategic partners to achieve maximum benefit for all [3]. While a BM is a presentation of the current business logic of an enterprise, $\mathrm{BMI}$ is defined as an activity or a process in which core elements of an enterprise and its business logic are purposely transformed [10-14] to achieve operational and strategic advancements $[7,15]$. 
There are different drivers that stimulate enterprises to innovate their BMs. For example, enterprises need to react on dynamic requests and changes in their business ecosystem. e.g., increasing cost-pressures, threats of easy substitution, and constant need for differentiation [5]. Existing BMI frameworks suggest several possible benefits of BMI, for example, competitive advantage, value creation and capture, knowledge creation, and the sustainable development of enterprise [16]. Fast development of new information technologies offers many opportunities to enterprises. New information technologies also enable the design of innovative and completely new BMs, which often bring disruptions to the existing industries and markets [1,17]. In these dynamic market conditions, no BM can be static and last forever. Every enterprise must continuously re-think, re-design, and develop its BM to remain competitive over time [18-21].

Past research has mainly focused on the definition of the BM $[8,20,22]$ and BMI concepts $[5,23]$, studying the antecedents and barriers to BMI $[11,24]$, and internal as well as external factors of BMI success $[11,20]$. Previous studies also addressed BMI activities in start-up enterprises [25,26]. Furthermore, some studies investigated the impact of information technologies and digitalization on BMI $[1,17,27,28]$. Less attention has been focused on the impact of BMI on performance $[29,30]$.

Recent BMI research has shifted towards industry-specific and interdisciplinary research. Authors have investigated strategic agility and BMI [31-33] and BMI and sustainability from the triple bottom line perspective [34-38] or the single perspective of sustainability, e.g., environmental performance [39]. Furthermore, recent research has focused towards sustainable BMI [40] and encouraged new studies on shared or polycentric BMI [41], circular BMs [42,43], platform BMs, or product-service systems [44-46].

However, most of the research has mainly focused on the investigation of BMI in large enterprises; only recently have several studies focused on small- and medium-sized enterprises (SMEs) $[1,14,31,35,47,48]$. As SMEs represent a key driving force of the European economy, more attention is needed in the understanding of their practices, innovativeness, and competitiveness in the global market [14,47-49]. Community Innovation Survey (CIS) data from Eurostat have shown that only about 1 in 20 SMEs has innovated its BM [47]. Even though recent research shows that SMEs seem to improve their business performance by innovating their BMs, their BMI practices are still relatively unknown and unclear [11,23,47]. Furthermore, most of the research methods applied in studies related to BMI in SMEs are predominantly case studies [50], which do not allow generalization of results. The evidence implies that despite all the research progress and developments, there is still a need to understand the fundamentals of BMI practices in SMEs.

Our study addresses the above-presented research gaps and focuses on the investigation of fundamental characteristics of BMI practices with a particular focus on SMEs. In the study, we aim to determine the drivers and outcomes of BMI and their impact on business performance in SMEs. In this relation, we aim to answer the following research questions: What drivers have an effect on BMI? What effects does BMI have on business performance? The first step in our study was an extensive literature review. Based on that, we have developed a research model and formulated hypotheses. To test the research model and hypotheses, we conducted a survey in 71 SMEs in Slovenia. Only enterprises with previous experience in BMI activities were involved in the study. For the analysis of the research model, we used a partial least squares path modeling (PLS-PM) method.

The identification and understanding of drivers and outcomes of BMI and their impact on business performance will contribute to the existing body of knowledge and further conceptualization of BMI practices in the context of SMEs. In addition, research results will enable policymakers to set up proper policies to stimulate SMEs BMI activities and raise their innovativeness. SMEs will gain a deeper understanding of the BMI phenomenon. This will enable them to better prepare for planned and systematic BMI activities needed to sustain competitiveness in a nowadays dynamic economy.

Further, in the paper we present regional entrepreneurship characteristics of SMEs and a literature review that guided the research model development and formulation of hypotheses. Next, we present the research methodology, discuss results, implications, limitations, and future research directions. 


\section{Literature Review and Hypotheses Development}

\subsection{Characteristics of SMEs and Their Innovativeness}

Slovenia is a small country with 2 million inhabitants. According to the Statistical Office of the Republic of Slovenia, there were 51,655 enterprises in Slovenia in 2017; out of these 51,309 were SMEs, which accounts for $99.3 \%$. Up to date, there were no statistical reports on BMI activities in SMEs in Slovenia, except our study on a population of 71 SMEs with prior experiences with BMI. Some regional authors focused on analyses of BMs through theory to deepen the understanding of the fundamental definitions of BMs [51], others explored the role of information in communication technology (ICT) capabilities in the internationalization of SMEs [27]. One study explains the importance of factors of BMs for the cloud computing adoption [52], while another study explains the insights of BMI practices in four case studies [48].

However, there is some information available on innovation activities in SMEs from the year 2012-2014 that offer some insights in the field. The report on innovativeness of Slovene SMEs states that $46 \%$ of all SMEs are innovation-active [53]. Furthermore, the research of innovation activities among enterprises in the period 2014-2016 shows that smaller enterprises are less innovative than their larger counterparts are [54]. In the observed period, $29 \%$ of all innovation active enterprises introduced only technological innovation and $21 \%$ of all innovation-active enterprises introduced only non-technological innovations. Both technological and non-technological innovations were introduced by half of innovation-active enterprises. Technological innovation-active enterprises introduced both product and process innovations in $37 \%$ of cases. A total of $28 \%$ of enterprises introduced only product innovations, $24 \%$ only process innovations, and $11 \%$ started the innovation activity but have not yet finished. Almost $46 \%$ of enterprises introduced both types of non-technological innovations (organizational and marketing), only organizational innovation was introduced by $25 \%$ of enterprises, and only marketing innovation by $29 \%$ of all non-technological innovative enterprises [54].

\subsection{Conceptualization of $B M$ and the Level of BMI}

BMs and BMI concepts have their foundation in corporate practices, strategic management, and economics $[5,55]$. Both concepts have gained increasing attention in the late 1990s and early 2000s $[8,24,56]$ when internet-based business emerged [57]. Despite almost two decades of research, there is still a lack of sound academic conceptualization of BMs [14,58,59] and BMI [6].

In general, the concept of a BM is referred to as a representation of the enterprise's logic and the way an enterprise creates, distributes, and captures value for its stakeholders [60,61]. While BMs have been investigated by many researchers from various disciplines, there is a wide variety of definitions [51]. In this paper, we define $\mathrm{BM}$ as a description of how an enterprise or network of enterprises creates and captures value for its stakeholders, (networked) enterprises, and the customers [62].

BMI is defined as the activity-based perspective of BMs, resulting in changes in an enterprise's $\mathrm{BM}$ that is new to the world or just new to the enterprises under analysis [4]. BMI results in reconfiguration of activities in the existing $\mathrm{BM}$ of an enterprise that is new to the market in which enterprise competes [57]. It is a process that deliberately changes the core elements of an enterprise and its business logic [10].

Several researchers [21,63] have provided an overview of BM components. Furthermore, some researchers provided BM ontologies, for example, BM Canvas [9], STOF (business model described from four interrelated perspectives: service, technology, organization, and finance) [64], and VISOR (framework for the Network Digital Industry that incorporates five interacting components: value proposition, interface experience, service platform, organizing model, revenue/cost sharing) [65]. The practitioner-oriented BM Canvas [9] consists of nine building blocks, including value proposition, key partners, key resources, key activities, customer relationship, communication and distribution 
channels, customer segmentation, revenue streams, and cost structure. Several researchers have used these components in their studies [2,66].

Several authors measure BMI components differently. For instance, Santos et al. [57] considered changes in the architecture of BMs as an indicator of BMI. Foss and Saebi [23] suggest that BMI literature provides two diverse perspectives of BMI, including changes in the architecture of a BM and changes in one or more components in BMs. Therefore, they suggested two-dimensions of BMI: scope and novelty. The scope dimension is characterized via architectural and modular changes of BM while the novelty dimension describes BM changes as being novel to an enterprise or an industry. Another valuable conceptualization is provided by Clauss [67] who developed a validated scale for BMI. In our study, we perceived four levels of BMI: BMs new to the industry, BMs never implemented by competitors before, BMs not found in dominant BMs in industry, and BMs not invented by other enterprises.

\subsection{Drivers of the Level of $B M I$}

Previous studies have revealed that drivers influencing BMI activities and practices may be different in nature, placed at different levels, and can be either internal or external to the enterprise [23,68]. In the context of the external environment, previous studies identified the following drivers: changing demands of stakeholders [69], changes in the competitive environment [26,70], and opportunities of new information and communication technologies $[1,17,71,72]$. Previous studies have shown mixed results about the impact of the business environment drivers on BMI. For example, one of the recent studies [1] has shown that the correlation between competitive intensity and BM experimentation was not supported. However, there have been only a few studies that have empirically tested the effects of different drivers on the propensity to engage in BMI [23,26].

In this study, we perceive the business environment as an external driver influencing SMEs' level of BMI. The business environment as an external driver influencing BMI consists of competitive intensity [73] and market turbulence [73,74]. In our research, it encompasses competitors and customers' dynamic behavior in the market. Based on previous research results, we hypothesize that:

Hypothesis 1 (H1). The business environment has a positive effect on the level of BMI.

Previous research also describes BMI as an attempt to seize new opportunities, for example, new information technologies [1,23,75]. Most of the previous research is based on case studies [23]. Some researchers have focused on the impact of information technologies on the emergence of new BMs in the context of e-commerce [71,72,76]. In addition, previous studies have shown that technology turbulence has a direct impact on BM experimentation $[1,74,77]$. The technology innovation has been identified as an important determinant of effective business, a driver for BM change and innovation and even a driver for the design of new disruptive BMs. Therefore, we hypothesize that:

Hypothesis 2 (H2). Information technology has a positive effect on the level of BMI.

The BMI concept is based on an enterprise's ability to leverage their internal capabilities and resources to innovate their BM [4]. Innovation in this study is seen as an internal driver and is defined as an enterprise's ability or capacity to introduce new processes or a new product/service in the enterprise [78]. The innovation can drive SMEs' experimentations in BMI. For instance, prior research has shown a positive relationship between innovation activity and BM experimentation [1]. Hence, we hypothesize that:

Hypothesis 3 (H3). Innovativeness has a positive effect on the level of BMI. 


\subsection{Outcomes of BMI}

BMI is defined as the activity-based perspective of BM, resulting in changes in an enterprise's business logic. More specifically, BMI leads towards changes in the BM architecture; either in one or more components in the BM $[4,23,57]$. In our research, we observe outcomes as changes in business processes standardization and integration, as well as changes in information and communication applications and infrastructure as a result of BMI activities [79,80].

Previous research has shown that BMI activities are related to BMI outcomes [1,14]. Foss and Saebi [23] offers the dimensionalization of BMI in terms of "scope" and "novelty." Dimension "scope" is related to the amount of architectural and modular changes in BM, while dimension "novelty" is related to whether the innovations in BM are new to the firm, to the industry, or to the world $[23,81]$. In our research, the level of BMI refers to the level of novelty of BMI for the enterprise or the industry. Therefore, we hypothesize that:

Hypothesis 4 (H4). Level of BMI has a positive effect on BMI outcomes.

The performance of the enterprise is one of the most important indicators for the evaluation of business results [82]. The relationship between BMI and business performance has been confirmed by several previous studies $[29,55,83,84]$. For example, studies have shown that different types of BM changes can lead to improved business performance [85]. Previous studies have shown that enterprise performance can be measured by financial and non-financial indicators, or by combining both [86]. In our study, we focus only on several dimensions, which are conceptualized as sales and profit growth, market share, value and penetration rate, and net income $[83,87]$. Hence, we hypothesize that:

Hypothesis 5 (H5). BMI outcomes have a positive effect on performance.

Figure 1 presents our research model, developed from the literature review. It consists of the above-defined hypotheses.

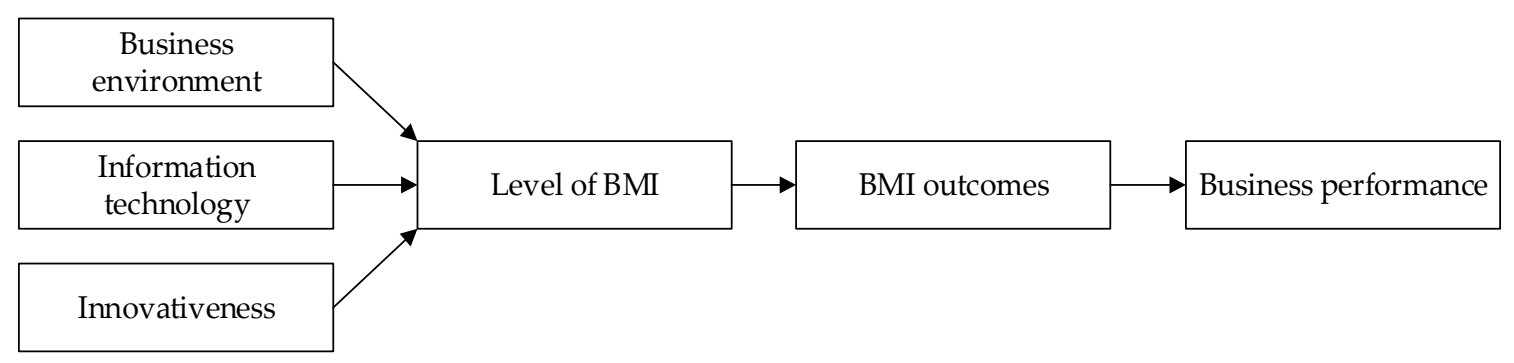

Figure 1. Research model.

\section{Methods}

\subsection{Measurement Model}

Based on the literature review on BMs, BMI, strategic management, and entrepreneurship, a comprehensive list of validated measures was generated. The questionnaire was extensive and consisted of several questions regarding BMs and BMI practices, including BMI drivers, types of innovations, changes of BMs, ontologies and tools used for BMI, BMI outcomes, performance, and background characteristics of enterprises.

In order to set up the empirical analysis for our study, we defined constructs for the regression. From the questionnaire, only the questions related to the items relevant for the defined constructs in the research model (Figure 1) were used for further analysis. To capture the business environment construct, items from Jaworski and Kohli [73] and Johnson et al. [74] were adapted and used in this study. For information technology construct, items were adapted from Bouwman et al. [1], 
Marolt et al. [48], and Bouwman et al. [74]. For the innovativeness construct, items were adopted from previous studies [78,88-91]. To measure the level of BMI construct, items considering the novelty of BMI were adopted from Osterwalder et al. [8] and Zott and Amit [22]; Ross et al. [79] items were used to measure the BMI outcomes construct. For the business performance construct, items were adapted from previous studies $[83,86,92,93]$. The constructs and respective measurement items are presented in Table 1.

Table 1. Constructs and items used in this study.

\begin{tabular}{|c|c|c|}
\hline Construct & Items & Sources \\
\hline Innovativeness & $\begin{array}{l}\text { Managers encourage employees to "think outside of the box." (Q13_1) } \\
\text { Our corporate culture is focused on constant innovation (Q13_2) } \\
\text { Original ideas are highly valued (Q13_3) } \\
\text { Our enterprise accepts risks (Q13_4) } \\
\text { Our enterprise shows perseverance in turning ideas into reality (Q13_5) } \\
\text { Our enterprise is able to identify new opportunities (Q13_6) } \\
\text { Our enterprise aims to create multiple innovations annually (Q13_7) } \\
\text { Our enterprise introduces innovations that are completely new to the market (Q13_8) } \\
\text { Creating more than one innovation at the same time is common practice in our } \\
\text { enterprise (Q13_9) } \\
\text { Our enterprise is one of the first to introduce innovations }\left(Q 13 \_10\right) \\
\text { Our enterprise often waits for some time before introducing innovations (Q13_11) } \\
\text { Our enterprise only introduces innovations because of others, e.g., customers, } \\
\text { suppliers, third parties (Q13_12) } \\
\text { Our enterprise is often the last one to introduce innovations (Q13_13) }\end{array}$ & {$[78,88-91]$} \\
\hline Level of BMI & $\begin{array}{l}\text { Changes in our BM that are new to our industry (Q6_1) } \\
\text { Changes in our BM that have never been implemented by competitors before (Q6_2) } \\
\text { Changes in our BM that cannot be found in the dominant BM of our industry (Q6_3) } \\
\text { Focus on a complete new market segment (Q6_4) } \\
\text { New ways to transact with customers (Q6_5) } \\
\text { New ways of organizing relations with customers (Q6_6) } \\
\text { Changes are the result of internal proposals (Q6_7) } \\
\text { Changes are not invented by other enterprises (Q6_8) } \\
\text { Changes are unlike any existing business (Q6_9) }\end{array}$ & {$[8,22]$} \\
\hline $\begin{array}{c}\text { Business } \\
\text { performance }\end{array}$ & $\begin{array}{l}\text { Sales growth of the enterprise (Q14_1) } \\
\text { Profit growth of the enterprise (Q14_2) } \\
\text { Market share (Q14_3) } \\
\text { Speed to market (Q14_4) } \\
\text { Market penetration rate (size) (Q14_5) } \\
\text { Market value (Q14_6) } \\
\text { Net income (Q14_7) } \\
\text { Return on investment (ROI) (Q14_8) } \\
\text { Customer loyalty (Q14_9) } \\
\text { Net profit margins (Q14_10) }\end{array}$ & {$[83,86,92,93]$} \\
\hline
\end{tabular}

A seven-point Likert type scale (1-totally disagree, 7-totally agree) was used to measure the level of agreement with given statements in the questionnaire. For the descriptive statistics, we used the Statistical Package for the Social Sciences (IBM SPSS Statistics, version 24) software, while R 
software, version 3.5.1 (Partial Least Squares Path Modeling package [94]) was applied to test the research model. The partial least squares path modeling (PLS-PM) technique is applicable when dealing with a relatively complex model and the sample size is small [95].

\subsection{Sample and Data Collection}

The empirical data were collected through a professional research agency based in the Netherlands in January and February 2017. Quota for micro-, small-, and medium-sized enterprises was established as 33, 33, and 33 percent. No quota was defined for industry sectors. The SMEs (using the definition by 2003/361/EC (2003)) were randomly selected from the Dun and Bradstreet database that collects data on enterprises on a regular basis from the Chambers of Commerce and other organizations. Key respondents (owners or BMI managers) were interviewed by native speakers through a computer-assisted telephone survey. The research agency took into account the incidence rate that provided the hit rate. This is the number of times an enterprise was asked, and if they were involved in BMI activities before founding one that fulfilled this requirement. In the end, 71 SMEs in Slovenia, which fulfilled the criteria of previous engagement in BMI activities, were identified and interviewed. These 71 interviewed SMEs formed the sample for this study.

\section{Results}

\subsection{Descriptive Statistics}

Table 2 presents a comparison of the sample structure of SMEs by industry with the actual structure of SMEs in Slovenia reported by the Statistical Office of the Republic of Slovenia in 2017. The standard Nomenclature of Economic Activities (NACE) classification for each industry type was used. A goodness-of-fit chi-square test confirmed no significant differences between observed and expected frequencies for the five largest categories by a number of observations acquired by sample, namely manufacturing, construction, accommodation, and food service, professional, scientific and technical activities, and wholesale and retail categories. The chi-square goodness-of-fit test is unreliable for categories with less than five observations in the sample [96]. Therefore, we were not able to perform this test for the remaining categories. Taking into account this limitation, the sample structure partially corresponded to the SME population in Slovenia.

Table 2. Number of SMEs by industry comparison with sample.

\begin{tabular}{ccccc}
\hline & $\begin{array}{c}\text { N of SMEs by } \\
\text { Industry }\end{array}$ & $\begin{array}{c}\text { \% of SMEs by } \\
\text { Industry }\end{array}$ & $\begin{array}{c}\text { Sample N SMEs } \\
\text { by Industry }\end{array}$ & $\begin{array}{c}\text { Sample \% of } \\
\text { SMEs by Industry }\end{array}$ \\
\hline Construction & 7457 & 14.53 & 13 & 18.31 \\
\hline Manufacturing & 7927 & 15.45 & 11 & 15.49 \\
\hline $\begin{array}{c}\text { Wholesale and retail trade; repair of } \\
\text { motor vehicles and motorcycles }\end{array}$ & 9356 & 18.23 & 10 & 9.86 \\
\hline $\begin{array}{c}\text { Accommodation and food } \\
\text { service activities }\end{array}$ & 4686 & 9.13 & 7 & 7.04 \\
\hline $\begin{array}{c}\text { Financial and insurance activities } \\
\text { Professional, scientific, and } \\
\text { technical activities }\end{array}$ & 497 & 0.97 & 5 & 7.04 \\
\hline $\begin{array}{c}\text { Administrative and support } \\
\text { service activities }\end{array}$ & 6256 & 12.19 & 5 & 5.63 \\
\hline Transportation and storage & 1588 & 3.09 & 4 & 5.63 \\
\hline $\begin{array}{c}\text { Water supply; sewerage, } \\
\text { waste management, and } \\
\text { remediation activities }\end{array}$ & 3626 & 7.07 & 4 & 5.63 \\
\hline $\begin{array}{c}\text { Other service activities } \\
\text { Education }\end{array}$ & 236 & 0.46 & 4 & 5.63 \\
\hline
\end{tabular}


Table 2. Cont.

\begin{tabular}{|c|c|c|c|c|}
\hline & $\begin{array}{l}\text { N of SMEs by } \\
\text { Industry * }\end{array}$ & $\begin{array}{l}\% \text { of SMEs by } \\
\text { Industry }\end{array}$ & $\begin{array}{l}\text { Sample N SMEs } \\
\text { by Industry }\end{array}$ & $\begin{array}{c}\text { Sample } \% \text { of } \\
\text { SMEs by Industry }\end{array}$ \\
\hline $\begin{array}{c}\text { Human health and social } \\
\text { work activities }\end{array}$ & 1948 & 3.80 & 1 & 1.41 \\
\hline Arts, entertainment, and recreation & 815 & 1.59 & 1 & 1.41 \\
\hline Information and communication & 1688 & 3.29 & 1 & 1.41 \\
\hline
\end{tabular}

${ }^{*}$ For microenterprises, only enterprises with 2-9 employees were taken into account.

Out of 71 respondents, 39.4 percent represented microenterprises, 36.6 percent were small enterprises, and 23.9 percent were medium-sized enterprises. All the enterprises had experience with BMI activities; however, only 25 percent of them innovated their BM in the last two years. Enterprises operated in different industries. Most of them were in the construction industry, manufacturing, and wholesale and retail trade. Other industries were less represented.

\subsection{Validity and Reliability}

We used R software to analyze the data. By using Dillon-Goldstein's rho (DG. Rho), average variance extracted (AVE), and composite reliability (CR), the convergent and discriminant validity and internal consistency of all components were examined. Table 3 illustrates the factor loadings (the items that have loadings less than a threshold value of 0.60 were removed, one item at a time), mean, standard deviation, DG. Rho, AVE, and CR for the model components. All displayed components have acceptable validity and reliability for the used measurements.

Table 3. Descriptive statistics, convergent validity, and internal consistency of the model.

\begin{tabular}{|c|c|c|c|c|c|c|c|}
\hline Construct & Items & Factor Loadings & Mean & Std. dev. & DG. Rho & AVE & CR \\
\hline \multirow{3}{*}{$\begin{array}{c}\text { Business } \\
\text { environment }\end{array}$} & Q12_4 & 0.78 & 3.91 & 1.81 & \multirow{3}{*}{0.78} & \multirow{3}{*}{0.54} & \multirow{3}{*}{0.78} \\
\hline & Q12_5 & 0.71 & 3.69 & 1.78 & & & \\
\hline & Q12_6 & 0.71 & 4.75 & 1.66 & & & \\
\hline \multirow{2}{*}{$\begin{array}{l}\text { Information } \\
\text { technology }\end{array}$} & Q12_7 & 0.94 & 3.98 & 1.73 & \multirow{2}{*}{0.95} & \multirow{2}{*}{0.9} & \multirow{2}{*}{0.95} \\
\hline & Q12_8 & 0.95 & 3.94 & 1.64 & & & \\
\hline \multirow{5}{*}{ Innovativeness } & Q13_2 & 0.75 & 4.69 & 1.56 & \multirow{5}{*}{0.86} & \multirow{5}{*}{0.55} & \multirow{5}{*}{0.86} \\
\hline & Q13_7 & 0.67 & 4.28 & 1.79 & & & \\
\hline & Q13_8 & 0.81 & 3.27 & 1.87 & & & \\
\hline & Q13_9 & 0.67 & 3.42 & 1.78 & & & \\
\hline & Q13_10 & 0.78 & 3.17 & 1.87 & & & \\
\hline \multirow{4}{*}{ Level of BMI } & Q6_1 & 0.84 & 3.38 & 1.88 & \multirow{4}{*}{0.87} & \multirow{4}{*}{0.62} & \multirow{4}{*}{0.87} \\
\hline & Q6_2 & 0.80 & 2.39 & 1.73 & & & \\
\hline & Q6_3 & 0.71 & 3.35 & 2.01 & & & \\
\hline & Q6_8 & 0.81 & 3.03 & 2.10 & & & \\
\hline \multirow{4}{*}{ BMI outcomes } & Q9_4 & 0.84 & 3.70 & 1.71 & \multirow{4}{*}{0.91} & \multirow{4}{*}{0.71} & \multirow{4}{*}{0.91} \\
\hline & Q9 5 & 0.90 & 3.41 & 1.58 & & & \\
\hline & Q9_6 & 0.85 & 3.73 & 1.84 & & & \\
\hline & Q9_7 & 0.78 & 3.55 & 1.72 & & & \\
\hline \multirow{6}{*}{$\begin{array}{l}\text { Business } \\
\text { performance }\end{array}$} & Q14_1 & 0.88 & 4.08 & 1.55 & \multirow{6}{*}{0.95} & \multirow{6}{*}{0.74} & \multirow{6}{*}{0.94} \\
\hline & Q14_2 & 0.92 & 3.94 & 1.56 & & & \\
\hline & Q14_3 & 0.87 & 3.96 & 1.59 & & & \\
\hline & Q14_5 & 0.80 & 4.11 & 1.50 & & & \\
\hline & Q14_6 & 0.85 & 4.07 & 1.47 & & & \\
\hline & Q14_7 & 0.85 & 4.11 & 1.67 & & & \\
\hline
\end{tabular}

Note: Number of observations for all items, $\mathrm{N}=71$.

Dillon-Goldstein's rho values were all above the threshold of 0.70 . The AVE values ranged from 0.54 to 0.95 , which is above the recommended threshold of 0.50 . Therefore, we can conclude that there was internal consistency between the items. After the internal consistency was tested, we examined the discriminant validity. Table 4 shows that values for the established discriminant validity were 
larger than other correlation values among the latent variables [97]. Based on this, we can determine that discriminant validity was not an issue.

Table 4. Discriminant validity of measurement model.

\begin{tabular}{ccccccc}
\hline & BENV & ITECH & INNOV & LBMI & BMIO & BPERF \\
\hline Business environment & 0.74 & & & & & \\
Information technology & 0.63 & 0.95 & & & & \\
Innovativeness & 0.38 & 0.40 & 0.74 & & & \\
Level of BMI & 0.46 & 0.40 & 0.54 & 0.79 & & \\
BMI outcomes & 0.40 & 0.54 & 0.49 & 0.56 & 0.84 & \\
Business performance & 0.33 & 0.32 & 0.29 & 0.38 & 0.29 & 0.86 \\
\hline
\end{tabular}

\subsection{Structural Model Analysis and Hypotheses Testing}

The structural model was assessed using the coefficient of determination $\left(R^{2}\right)$, the values of the beta coefficients, and their level of significance. The $\mathrm{R}^{2}$ value of the variable level of BMI and BMI outcomes were 0.37 and 0.46 , respectively, while that of business performance was 0.08 .

The results are presented in Figure 2 and show that four out of five hypotheses were supported. Business environment and innovativeness had a positive direct impact on the level of BMI ( $\beta=0.26$, $p<0.05$ and $\beta=0.41, p<0.01$, respectively), while information technology had no direct impact on the level of BMI. Moreover, the level of BMI was found to have a positive direct impact on BMI outcomes $(\beta=0.56, p<0.01)$. Similarly, BMI outcomes had a positive direct impact on business performance $(\beta=0.29, p<0.05)$.

We also evaluated the goodness of model fit for the structural model by examining the goodness-of-fit index (GFI). The GFI value was 0.46 , which is considered to be a slightly large effect size of $\mathrm{R}^{2}$, thus indicating an adequate global validation of the overall PLS model. Table 5 provides detailed information of direct, indirect, and total effects.

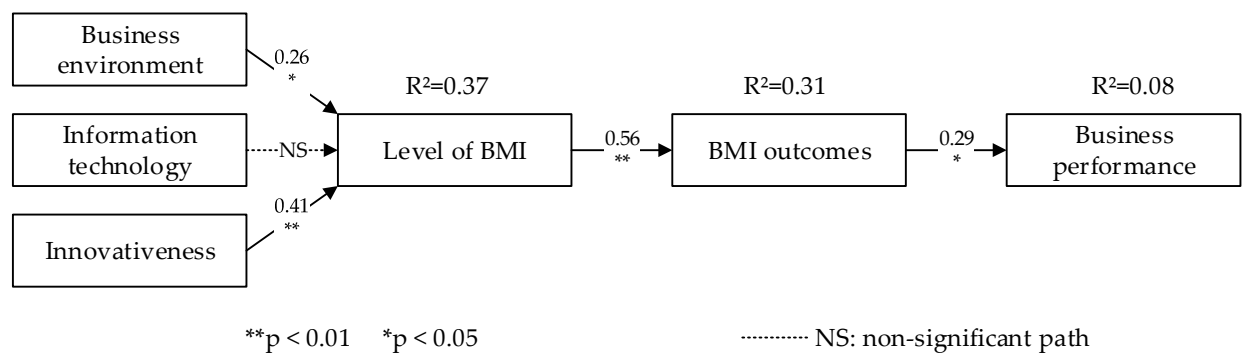

Figure 2. Empirical results.

Table 5. Direct, indirect, and total effects.

\begin{tabular}{cccc}
\hline Relationships & Direct Effects & Indirect Effects & Total Effects \\
\hline Business environment $\rightarrow$ Information technology & 0.00 & 0.00 & 0.00 \\
Business environment $\rightarrow$ Innovativeness & 0.00 & 0.00 & 0.00 \\
Business environment $\rightarrow$ Level of BMI & 0.26 & 0.00 & 0.26 \\
Business environment $\rightarrow$ BMI outcomes & 0.00 & 0.15 & 0.15 \\
Business environment $\rightarrow$ Business performance & 0.00 & 0.04 & 0.04 \\
Information technology $\rightarrow$ Innovativeness & 0.00 & 0.00 & 0.00 \\
Information technology $\rightarrow$ Level of BMI & 0.07 & 0.00 & 0.07 \\
Information technology $\rightarrow$ BMI outcomes & 0.00 & 0.04 & 0.04 \\
Information technology $\rightarrow$ Business performance & 0.00 & 0.01 & 0.01 \\
Innovativeness $\rightarrow$ Level of BMI & 0.41 & 0.00 & 0.41 \\
Innovativeness $\rightarrow$ BMI outcomes & 0.00 & 0.23 & 0.23 \\
Innovativeness $\rightarrow$ Business performance & 0.00 & 0.07 & 0.07 \\
Level of BMI $\rightarrow$ BMI outcomes & 0.56 & 0.00 & 0.56 \\
Level of BMI $\rightarrow$ Business performance & 0.00 & 0.17 & 0.17 \\
BMI outcomes $\rightarrow$ Business performance & 0.29 & 0.00 & 0.29 \\
\hline
\end{tabular}




\section{Discussion}

\subsection{Implications for Theory}

The empirical results revealed that the business environment as an external driver has a positive direct impact on the level of BMI. These research results support theoretical foundations determining that the variety of internal and external drivers stimulates BMI [23]. Among external drivers, changing demands from stakeholders [69] and competitive environment [26], as well as information and communication technologies $[1,71,98]$, are highlighted. However, in our study, no direct impact of information technology was found on the level of BMI. These findings counter results from the recent study confirming positive association of information technology with BMI [1]. A possible explanation of these results might be that this study has focused on the investigation of the impact of rapid development and fast changing information technology as a tangible resource, while the intangible technology assets (e.g., specialized IT personnel and skilled employees) may be more crucial for the exploitation of information technology opportunities. Therefore, the results of this study support the idea that technology per se does not play a key role in the BMI. Furthermore, $39.4 \%$ of SMEs were micro-, $36.6 \%$ were small-, and $23.9 \%$ were medium-sized enterprises, predominantly from construction, manufacturing, wholesale, and accommodation and food industry. Enterprises in these industries traditionally do not rely on modern ICT. This was also supported with a recent report from the Statistical Office of the Republic of Slovenia in 2018. The report indicated that among small- and medium-sized enterprises, a large proportion of those had a low digital index ( $41 \%$ and $46 \%$, respectively) [99].

Results of the study also revealed that an enterprise's innovativeness as an internal driver has a positive direct impact on the level of BMI activities. Innovativeness is perceived as an ability or capacity to introduce new processes or a new product/service to the enterprise [78]. Results were aligned with theoretical foundations suggesting that the BMI concept is based on an enterprise's ability to leverage their internal capabilities and resources to innovate their BMI [4]. These suggestions were recently confirmed in the study in Bouwman et al. [1] that showed a positive relationship between innovation activity and BM experimentation.

The level of BMI construct is presented by the level of novelty of BMI, which might be new to the enterprise or to the industry. The results of our study suggest a positive direct impact of the level of BMI on BMI outcomes. These results are aligned with previous research suggesting that BMI activities result in BMI outcomes [1,14], which lead to higher business performance.

The BMI outcomes are perceived as changes in BM. In our study, we focused on the observation of changes caused by BMI activities leading to changes in business processes and in information technology. As hypothesized in this study, the BMI outcomes had a positive direct impact on an enterprise's overall business performance. The results are aligned with previous studies that have confirmed the relationship between BMI activities and business performance $[29,55,83,84]$. Moreover, the results are consistent with the study conducted by Giesen et al. [85] that provides insights on how different types of BM changes can lead to improved business performance. Overall, our study has confirmed that the cogent changes in BM lead to the improved overall business performance of the SMEs.

\subsection{Practical Implications}

The results of our study confirmed that nowadays, the dynamic and competitive business environment with more demanding, frequently changing customer preferences influences BMI activities in enterprises. The pressure from the business environment motivates SMEs to innovate their BMs differently than their competition. It seems that more innovative SMEs are more prone to innovate their BMs and are able to change them in a way that are different from BMs of their competitors. Surprisingly, in our research, SMEs did not recognize information technology as having an impact on the level of BMI novelty. Information technology was often identified as an enabler and a supporter in 
the realization of an enterprise's strategy and goals. However, according to a recent report from the Organization for Economic Co-operation and Development (OECD), the lack of investments, as well as lack of personnel, knowledge, and skills, hinder the adoption of digital technologies in SMEs [49].

Although BMI is one of the key activities that has to be continuously undertaken in every enterprise, either to survive or to achieve growth [100], our results revealed a lower degree of systematic and continuous approach to BMI in micro-, small-, and medium-sized enterprises in Slovenia. The results indicate that only 25 percent out of 71 enterprises with previous experiences in $\mathrm{BMI}$ innovated their BM in the last 2 years. In addition, the agency performing the survey reported to have difficulties identifying SMEs in Slovenia with previous experiences in BMI. This situation is aligned with results of Barjak et al. [47], indicating that only 1 out of every 20 SMEs has innovated their BM.

Our observations and awareness of challenges that many SMEs face with, e.g., a limited number of employees, knowledge, and skills, have confirmed the limited use of BM methods (e.g., Canvas) and tools (e.g., spreadsheets like Excel) for BMI [101]. As already exposed by Florén and Agostini [102], many enterprises have difficulties in finding proper approaches, methods, and tools for systematic business model innovation. Consequently, managers/owners of SMEs do not have a complete overview of how their enterprise creates, captures, and delivers value for their networked enterprises and the customers. This may lead to inefficient decision-making, overall inefficiency, and lower competitiveness. Therefore, if SMEs want to successfully innovate their BM, they need to use available BM methods and tools more systematically and comprehensively. Enterprises need to be aware that systematic and cogent changes in the individual elements of BMs are not only made to satisfy customers but also to differentiate themselves from the competition and achieve competitive advantages. SMEs may also exploit the benefits of a shared polycentric BMI. The benefit of a polycentric innovation approach is that new forms of value (positive effect) emerge spontaneously from the bottom-up, producing a dispersed and multilevel pattern of innovation at different levels of the enterprise [41].

To overcome these challenges, a better understanding of drivers that encourage SMEs for BMI and in-depth understanding of good practices and approaches implemented by successful enterprises is needed. Special attention should be paid to raise the awareness of SMEs about the importance of BMI, available methods, and tools. While training and usage of methods and tools is well represented in startup programs, well-established enterprises seem to have less knowledge and support in this field. They often rely on their intuition and use nonsystematic approaches.

It is notable that there are many online resources and materials available in different forms, for example: Business Makeover portal (http://buisinessmakeover.eu) presenting best practice cases, scenarios, and tools for BMI; Business model canvas and strategyzer tool for BMI (https:/ / strategyzer. com); massive online courses with certification (https://online-learning.tudelft.nl/professionalcertificate/business-model-innovation/); etc. However, many SMEs perceive self-learning activities as additional, time-consuming effort, while they would rather focus on daily business activities. Therefore, training programs through a means of seminars, coaching, and train-the-trainer programs may be more aligned with SMEs needs.

As SMEs represent most of the Slovenian economy, the government needs to provide supportive environment for SMEs to boost their innovation potential. The environment should form an ecosystem of various stakeholders from universities, research institutes, regional development agencies, Chambers of Craft and Commerce, and other potential partners. In Slovenia, we observed the first steps towards such an ecosystem through Strategic Research and Innovation Partnership Program, established in 2017, and the Digital Innovation Hub, which was established at the national level in December 2018. Both initiatives form a network of many different partners with the aim to boost innovation potential and the digital transformation of enterprises in Slovenia. Education and training activities, including about BM and BMI approaches, methods, and tools, are among priorities of both programs. Governments may also stimulate and support SMEs innovativeness through a form of 
either a tax relief or alternative funding methods. Finally, but importantly, SMEs should put more emphasis on continuous learning and the development of digital skills.

\section{Conclusions}

Up to date, this is the first study focusing on the analysis of drivers and outcomes of BMI in SMEs in Slovenia. Among 71 Slovenian SMEs that have participated in the study, only 25 percent have innovated their BM in the last two years. However, all participating SMEs had experiences with BMI. It is interesting that for the purpose of the survey, it was hard to identify SMEs with previous experiences with BMI. This situation is consistent with a previous report of the European Union, where the data have shown that only 1 out of every 20 SMEs innovate their business model.

Overall, the results of the hypotheses testing suggest that internal as well as external drivers have a positive impact on SMEs level of BMI. However, the rapidly changing and fast-developing information technology was not recognized as having a direct impact on the level of BMI. Furthermore, the level of BMI had a positive impact on BMI outcomes. Moreover, the BMI outcomes had a positive impact on overall performance outcomes. This indicates the importance of continuous BMI activities for better business performance and competitiveness.

Even though this study has focused on several BMI issues and offers possible explanations for BMI practices in SMEs in Slovenia, there are also several limitations, which highlight opportunities for further research. First, the research findings were based only on the sample of 71 SMEs with prior BMI activities in Slovenia. The comparison of these findings with other European countries could provide further insights regarding differences in BMI drivers, practices, and outcomes. The responses of this study were provided only by the owners or managers who are involved in BMI. Therefore, further research could include employees of different roles in the enterprise (not only owners/managers, but also other employees who are involved in BMI), which may reflect in different perceptions of BMI. In addition, this study offers only partial insights on a vast area of BM and BMI research. Therefore, the future studies should give more emphasis on different drivers and more detailed BMI practices, as well as BMI outcomes. In this respect, case studies could deepen our understanding and provide valuable insights in best practices, as well as possible failures related to BMI activities and results. Nevertheless, according to recent developments, we suggest investigating the impact of BMI on business performance more in the sense of a triple bottom line, considering social, environmental, and economic returns in creating value, even in terms of corporate social responsibility [5]. Due to the complexity of the BM and BMI phenomena, we suggest a mixed-method approach, combining qualitative and quantitative studies to gain deeper insights and understanding of the investigated phenomena.

Author Contributions: Conceptualization, A.P., G.L., M.K.B., D.V., and M.M.; Data curation, M.M.; Formal analysis, M.M.; Funding acquisition, A.P., M.K.B., and M.M.; Investigation, A.P., G.L., D.V., and M.M.; Methodology, A.P., M.K.B., D.V., and M.M.; Project administration, A.P. and M.M.; Resources, A.P., G.L., M.K.B., and M.M.; Software, M.M.; Supervision, A.P., G.L., M.K.B., and M.M.; Validation, A.P. and M.M.; Visualization, M.M.; Writing—original draft, A.P. and M.M.; Writing—review and editing, A.P., G.L., M.K.B., D.V., and M.M.

Funding: The work leading to these results has received funding from European Unions's Horizon 2020 Research and Innovation Program (2014-2020) under grant agreement No. 645791. The content herein reflects only the authors' view. The European Commission is not responsible for any use that may be made of the information it contains.

Acknowledgments: This research was supported by the Slovenian Research Agency; Program No. P5-0018-Decision Support Systems in Digital Business.

Conflicts of Interest: The authors declare no conflict of interest.

\section{References}

1. Bouwman, H.; Nikou, S.; Molina-Castillo, F.J.; de Reuver, M. The impact of digitalization on business models. Digit. Policy Regul. Gov. 2018, 20, 105-124. [CrossRef]

2. Haaker, T.; Bouwman, H.; Janssen, W.; de Reuver, M. Business model stress testing: A practical approach to test the robustness of a business model. Futures 2017, 89, 14-25. [CrossRef] 
3. Nielsen, C.; Lund, M. Building Scalable Business Models. MIT Sloan Manag. Rev. 2018, 59, 65-69.

4. Zott, C.; Amit, R. Business model design: An activity system perspective. Long Range Plan. 2010, 43, $216-226$. [CrossRef]

5. Carayannis, E.G.; Sindakis, S.; Walter, C. Business Model Innovation as Lever of Organizational Sustainability. J. Technol. Transf. 2015, 40, 85-104. [CrossRef]

6. Schneider, S.; Spieth, P. Business model innovation: Towards and integrated research agenda. Int. J. Innov. Manag. 2013, 17, 1-34. [CrossRef]

7. Goyal, S.; Kapoor, A.; Esposito, M.; Sergi, B.S. Understanding business model-Literature review of concept and trends. Int. J. Compet. 2017, 1, 99-118. [CrossRef]

8. Osterwalder, A.; Pigneur, Y.; Tucci, C.L. Clarifying Business Models: Origins, Present, and Future of the Concept. Commun. Assoc. Inf. Syst. 2005, 15. [CrossRef]

9. Osterwalder, A.; Pigneur, Y. Business Model Generation: A Handbook for Visionaries, Game Changers, and Challengers; Wiley: Hoboken, NJ, USA, 2010; ISBN 0470876417.

10. Bucherer, E.; Eisert, U.; Gassmann, O. Towards Systematic Business Model Innovation: Lessons from Product Innovation Management. Creat. Innov. Manag. 2012, 21, 183-198. [CrossRef]

11. Hartmann, M.; Oriani, R.; Bateman, H. The Performance Effect of Business Model Innovation: An Empirical Analysis of Pension Funds. In Proceedings of the 35th DRUID Celebration Conference 2013, Barcelona, Spain, 17-19 June 2013.

12. Lindgardt, Z.; Reeves, M.; Stalk, G.; Deimler, M.S. Business Model Innovation: When the Game Gets Tough, Change the Game; The Boston Consulting Group: Boston, MA, USA, September 2009.

13. Pohle, G.; Chapman, M. IBM's global CEO report 2006: Business model innovation matters. Strateg. Leadersh. 2006, 34, 34-40. [CrossRef]

14. Heikkilä, M.; Bouwman, H.; Heikkilä, J. From strategic goals to business model innovation paths: An exploratory study. J. Small Bus. Enterp. Dev. 2018, 25, 107-128. [CrossRef]

15. Morris, M.; Schindehutte, M.; Allen, J. The entrepreneur's business model: Toward a unified perspective. J. Bus. Res. 2005, 58, 726-735. [CrossRef]

16. Wirtz, B.W.; Daiser, P. Business Model Innovation: An Integrative Conceptual Framework. J. Bus. Model. 2017, 5, 14-34.

17. Pucihar, A.; Lenart, G.; Marolt, M.; Borštnar, M.K.; Maletič, D. Role of ICT in business model innovation in SMEs-Case of Slovenia. In IDIMT 2016 Information Technology, Society and Economy Strategic Cross-Influences, Proceedings of the 24th Interdisciplinary Information Management Talks, Poděbrady, Czech Republic, 7-9 September 2016; Linz Trauner Verlag Linz Trauner Verlag: Linz, Austria, 2016.

18. Amit, R.; Zott, C. Creating Value Through Business Model Innovation. MIT Sloan Manag. Rev. 2012, 53, $41-49$.

19. Chesbrough, H. Business model innovation: It's not just about technology anymore. Strateg. Leadersh. 2007, 35, 12-17. [CrossRef]

20. Teece, D.J. Business models, business strategy and innovation. Long Range Plan. 2010, 43, 172-194. [CrossRef]

21. Zott, C.; Amit, R.; Massa, L. The Business Model: Recent Developments and Future Research. J. Manag. 2011, 37, 1019-1042.

22. Zott, C.; Amit, R. The fit between product market strategy and business model: Implications for firm performance. Strateg. Manag. J. 2008, 29, 1-26. [CrossRef]

23. Foss, N.J.; Saebi, T. Fifteen Years of Research on Business Model Innovation. J. Manag. 2017, 43, $200-227$. [CrossRef]

24. Amit, R.; Zott, C. Value creation in e-business. Strateg. Manag. J. 2001, 22, 493-520. [CrossRef]

25. Zhang, H.; Sun, X.; Lyu, C. Exploratory orientation, business model innovation and new venture growth. Sustainability 2017, 10, 56. [CrossRef]

26. De Reuver, M.; Bouwman, H.; MacInnes, I. Business models dynamics for start-ups and innovating e-businesses. Int. J. Electron. Bus. 2009, 7, 269-286. [CrossRef]

27. Hagsten, E.; Kotnik, P. ICT as facilitator of internationalisation in small- and medium-sized firms. Small Bus. Econ. 2017, 48, 431-446. [CrossRef]

28. Lyver, M.J.; Lu, T.J. Sustaining innovation performance in SMEs: Exploring the roles of strategic entrepreneurship and IT capabilities. Sustainability 2018, 10, 442. [CrossRef] 
29. Zott, C.; Amit, R. Business Model Design and the Performance of Entrepreneurial Firms. Organ. Sci. 2007, 18, 165-335. [CrossRef]

30. Desyllas, P.; Sako, M. Profiting from business model innovation: Evidence from Pay-As-You-Drive auto insurance. Res. Policy 2013, 42, 101-116. [CrossRef]

31. Arbussa, A.; Bikfalvi, A.; Marquès, P. Strategic agility-driven business model renewal: The case of an SME. Manag. Decis. 2017, 55, 271-293. [CrossRef]

32. Doz, Y.L.; Kosonen, M. Embedding strategic agility: A leadership agenda for accelerating business model renewal. Long Range Plan. 2010, 43, 370-382. [CrossRef]

33. Mace, R. Business Model Innovation, Business Model Enablers and the Strategic Agility Paradox. Ph.D. Thesis, Capella University, Minneapolis, MN, USA, 2016.

34. Geissdoerfer, M.; Vladimirova, D.; Evans, S. Sustainable business model innovation: A review. J. Clean. Prod. 2018, 198, 401-416. [CrossRef]

35. Battistella, C.; Cagnina, M.R.; Cicero, L.; Preghenella, N. Sustainable business models of SMEs: Challenges in yacht tourism sector. Sustainability 2018, 10, 3437. [CrossRef]

36. Bocken, N.M.P.; Short, S.W.; Rana, P.; Evans, S. A literature and practice review to develop sustainable business model archetypes. J. Clean. Prod. 2014, 65, 42-56. [CrossRef]

37. Bocken, N. Sustainable consumption through new business models: The role of sustainable enterpreneurship. In Sustainable Entrepreneurship Discovering, Creating and Seizing Opportunities for Blended Value Generation, 1st ed.; Lindgreen, A., Maon, F., Vallaste, C., Eds.; Routledge: New York, NY, USA, 2019; ISBN 9781472483591.

38. Schaltegger, S.; Hansen, E.G.; Lüdeke-Freund, F. Business Models for Sustainability: Origins, Present Research, and Future Avenues. Organ. Environ. 2016, 29, 3-10. [CrossRef]

39. Woo, C.; Chung, Y.; Chun, D.; Seo, H. Exploring the impact of complementary assets on the environmental performance in manufacturing SMEs. Sustainability 2014, 6, 7412-7432. [CrossRef]

40. Lüdeke-Freund, F.; Dembek, K. Sustainable business model research and practice: Emerging field or passing fancy? J. Clean. Prod. 2017, 168, 1668-1678. [CrossRef]

41. Nyangon, J.; Byrne, J. Diversifying Electricity Customer Choice: REVing Up the New York Energy Vision for Polycentric Innovation. In Energy Systems and Environment; Tsvetkov, P., Ed.; IntechOpen: London, UK, 2018; pp. 3-24, ISBN 978-1-78923-711-5.

42. Nußholz, J.L.K. Circular business models: Defining a concept and framing an emerging research field. Sustainability 2017, 9, 1810. [CrossRef]

43. Rizos, V.; Behrens, A.; van der Gaast, W.; Hofman, E.; Ioannou, A.; Kafyeke, T.; Flamos, A.; Rinaldi, R.; Papadelis, S.; Hirschnitz-Garbers, M.; et al. Implementation of circular economy business models by small and medium-sized enterprises (SMEs): Barriers and enablers. Sustainability 2016, 8, 1212. [CrossRef]

44. Piscicelli, L.; Ludden, G.D.S.; Cooper, T. What makes a sustainable business model successful? An empirical comparison of two peer-to-peer goods-sharing platforms. J. Clean. Prod. 2018, 172, 4580-4591. [CrossRef]

45. Chian Tan, F.T.; Cahalane, M.; Tan, B.; Englert, J. How GoGet CarShare's Product-Service System is Facilitating Collaborative Consumption. MIS Q. Exec. 2017, 16, 265-277.

46. Yang, M.; Evans, S.; Vladimirova, D.; Rana, P. Value uncaptured perspective for sustainable business model innovation. J. Clean. Prod. 2017, 140, 1794-1804. [CrossRef]

47. Barjak, F.; Niedermann, A.; Perrett, P. The Need for Innovations in Business Models_Final Policy Brief; European Commission: Brussels, Belgium, 2014; pp. 1-52.

48. Marolt, M.; Lenart, G.; Maletič, D.; Kljajić Borštnar, M.; Pucihar, A. Business Model Innovation: Insights from a Multiple Case Study of Slovenian SMEs. Organizacija 2016, 49, 161-171. [CrossRef]

49. OECD. Enhancing the Contributions of SMEs in a Global and Digitalised Economy. In Proceedings of the Meeting of the OECD Council at Ministerial Level, Paris, France, 7-8 June 2017.

50. Laudien, S.M.; Daxböck, B. Business model innovation processes of average market players: A qualitativeempirical analysis. RD Manag. 2017, 47, 420-430. [CrossRef]

51. DaSilva, C.M.; Trkman, P. Business model: What it is and what it is not. Long Range Plan. 2014, 47, 379-389. [CrossRef]

52. Habjan, K.B.; Pucihar, A. Cloud computing adoption business model factors: Does enterprise size matter? Eng. Econ. 2017, 28, 253-261.

53. Črnigoj Marc, T.; Svetin, I. Statistical Overview of Slovenia 2016; Statistical Office of the Republic of Slovenia: Ljubljana, Slovenia, 2016. 
54. Vidmar, D. Innovation Activity in Industry and Selected Services, Slovenia, 2014-2016; Statistical Office of the Republic of Slovenia: Ljubljana, Slovenia, 2018.

55. Aspara, J.; Hietanen, J.; Tikkanen, H. Business model innovation vs replication: Financial performance implications of strategic emphases. J. Strateg. Mark. 2010, 18, 39-56. [CrossRef]

56. Petrovic, O.; Kittl, C.; Teksten, R.D. Developing Business Models for Ebusiness; Elsevier: New York, NY, USA, 2010.

57. Santos, J.; Spector, B.; Van der Heyden, L. Toward a Theory of Business Model Innovation within Incumbent Firms; INSEAD Working Paper No. 2009/16/EFE/ST/TOM; INSEAD: Fontainebleau, France, 2009.

58. Goethals, F. The Unified Business Model Framework. Little Econ. Manag. 2009, 9, 1-47.

59. Mäkinen, S.; Seppänen, M. Assessing business model concepts with taxonomical research criteria: A preliminary study. Manag. Res. News 2007, 30, 735-748. [CrossRef]

60. Chesbrough, H.; Rosenbloom, R.S. The role of the business model in capturing value from innovation: Evidence from Xerox Corporation's technology spin-off companies. Ind. Corp. Chang. 2002, 11, 529-555. [CrossRef]

61. Bouwman, H.; Zhengjia, M.; van der Duin, P.; Limonard, S. A business model for IPTV service: A dynamic framework. Info 2008, 10, 22-38. [CrossRef]

62. Bouwman, H.; de Vos, H.; Haaker, T. Mobile Service Innovation and Business Models; Springer: Berlin, Germany, 2008; ISBN 9783540792383.

63. Lambert, S.C.; Davidson, R.A. Applications of the business model in studies of enterprise success, innovation and classification: An analysis of empirical research from 1996 to 2010. Eur. Manag. J. 2013, 31, 668-681. [CrossRef]

64. Bouwman, H.; Faber, E.; Haaker, T.; Kijl, B.; De Reuver, M. Conceptualizing the STOF Model. In Mobile Service Innovation and Business Models; Bouwman, H., de Vos, H., Haaker, T., Eds.; Springer Publishing Company, Incorporated: Berlin, Germany, 2008; pp. 31-70. ISBN1 3642098126. ISBN2 9783642098123.

65. El Sawy, O.A.; Pereira, F. Business Modelling in the Dynamic Digital Space; SpringerBriefs in Digital Spaces; Springer: Berlin/Heidelberg, Germany, 2013; ISBN 978-3-642-31764-4.

66. Hartmann, M.; Zaki, M.; Feldmann, N.; Neely, A. Capturing value from big data-A taxonomy of data-driven business models used by start-up firms. Int. J. Oper. Prod. Manag. 2016, 36, 1382-1406. [CrossRef]

67. Clauss, T. Measuring business model innovation: conceptualization, scale development, and proof of performance. RD Manag. 2017, 47, 385-403. [CrossRef]

68. Andreini, D.; Bettinelli, C. Business model innovation: From systematic literature review to future research directions. J. Manag. Gov. 2017, 21, 785-792.

69. Ferreira, F.N.H.; Proença, J.F.; Spencer, R.; Cova, B. The transition from products to solutions: External business model fit and dynamics. Ind. Mark. Manag. 2013, 42, 1093-1101. [CrossRef]

70. Voelpel, S.C.; Leibold, M.; Tekie, E.B. The wheel of business model reinvention: How to reshape your business model to leapfrog competitors. J. Chang. Manag. 2004, 4, 259-276. [CrossRef]

71. Pateli, A.G.; Giaglis, G.M. Technology innovation-induced business model change: A contingency approach. J. Organ. Chang. Manag. 2005, 18, 167-183. [CrossRef]

72. Wirtz, B.W.; Schilke, O.; Ullrich, S. Strategic development of business models: Implications of the web 2.0 for creating value on the internet. Long Range Plan. 2010, 43, 272-290. [CrossRef]

73. Jaworski, B.J.; Kohli, A.K. Market Orientation: Antecedents and Consequences. J. Mark. 1993, 57, 53-70. [CrossRef]

74. Johnson, M.W.; Christensen, C.M.; Kagermann, H. Reinventing Your Business Model. Harv. Bus. Rev. 2008, $86,143$.

75. Chesbrough, H. Business model innovation: Opportunities and barriers. Long Range Plan. 2010, 43, $354-363$. [CrossRef]

76. Timmers, P. Business Models for Electronic Markets. Electron. Mark. 1998, 8, 3-8. [CrossRef]

77. Marolt, M.; Maletič, D.; Borštnar, M.K.; Lenart, G.; Pucihar, A. Comparative Analysis of Business Model Ontologies. In Proceedings of the 35th International Conference on Organizational Science Development, Portoroz, Slovenia, 16-18 March 2016; Doucek, P., Novak, A.P.B., Eds.; Moderna Organizacija: Kranj, Slovenia, 2016; pp. 601-614.

78. Hult, G.T.M.; Hurley, R.F.; Knight, G.A. Innovativeness: Its antecedents and impact on business performance. Ind. Mark. Manag. 2004, 33, 429-438. [CrossRef] 
79. Ross, J.W.; Weill, P.; Robertson, D. Enterprise Architecture as Strategy: Creating a Foundation for Business Execution; Harvard Business School Press: Boston, MA, USA, 2006; ISBN 1591398398.

80. Marolt, M.; Lenart, G.; Kljajić Borštnar, M.; Vidmar, D.; Pucihar, A. SMEs Perspective on Business Model Innovation. In Proceedings of the 31th Bled eConference Digital Transformation-Meeting the Challenges, Bled, Slovenia, 18-21 June 2017; Pucihar, A., Kljajić Borštnar, M., Ravesteijn, P., Seitz, J., Bons, R., Eds.; University of Maribor Press: Maribor, Slovenia, 2018; pp. 577-591, ISBN 978-961-286-170-4.

81. Schumpeter, J.A. The Theory of Economic Development. An Inquiry into Profits, Capital, Credit, Interest, and the Business Cycle; Harvard Economic Studies; Harvard University Press: Cambridge, MA, USA, 1934; ISBN 9780674879904.

82. Pucci, T.; Nosi, C.; Zanni, L. Firm capabilities, business model design and performance of SMEs. J. Small Bus. Enterp. Dev. 2017, 24, 222-241. [CrossRef]

83. Cucculelli, M.; Bettinelli, C. Business models, intangibles and firm performance: Evidence on corporate entrepreneurship from Italian manufacturing SMEs. Small Bus. Econ. 2015, 45, 329-350. [CrossRef]

84. Volberda, H.; van den Bosch, F.; Heij, K. Reinventing Business Models: How Firms Cope with Disruption; Oxford University Press: Oxford, UK, 2017; ISBN 9780198792048.

85. Giesen, E.; Berman, S.J.; Bell, R.; Blitz, A. Three ways to successfully innovate your business model. Strateg. Leadersh. 2007, 35, 27-33. [CrossRef]

86. Venkatraman, N.; Ramanujam, V. Measurement of Business Performance in Strategy Research: A Comparison of Approaches. Acad. Manag. Rev. 1986, 11, 801-814. [CrossRef]

87. Shane, S.; Venkataraman, S. The promise of entrepreneurship as a field of research. In Entrepreneurship: Concepts, Theory and Perspective; Springer: Berlin/Heidelberg, Germany, 2007; ISBN 9783540485421.

88. Subramanian, A. Innovativeness: Redefining the concept. J. Eng. Technol. Manag. 1996, 13, $223-243$. [CrossRef]

89. Atuahene-Gima, K.; Ko, A. An Empirical Investigation of the Effect of Market Orientation and Entrepreneurship Orientation Alignment on Product Innovation. Organ. Sci. 2001, 12, 54-74. [CrossRef]

90. Calantone, R.J.; Cavusgil, S.T.; Zhao, Y. Learning orientation, firm innovation capability, and firm performance. Ind. Mark. Manag. 2002, 31, 515-524. [CrossRef]

91. Naman, J.L.; Slevin, D.P. Entrepreneurship and the concept of fit: A model and empirical tests. Strateg. Manag. J. 1993, 14, 137-153. [CrossRef]

92. Guo, H.; Tang, J.; Su, Z.; Katz, J.A. Opportunity recognition and SME performance: The mediating effect of business model innovation. RD Manag. 2017, 47, 431-442. [CrossRef]

93. Pati, R.K.; Nandakumar, M.K.; Ghobadian, A.; Ireland, R.D.; O'Regan, N. Business model design-performance relationship under external and internal contingencies: Evidence from SMEs in an emerging economy. Long Range Plan. 2018, 51, 750-769. [CrossRef]

94. Sanchez, G.; Trinchera, L.; Russolillo, G. plspm: Tools for partial least squares path modeling (PLS-PM). Available online: https:/ / rdrr.io/cran/plspm/ (accessed on 11 January 2019).

95. Chin, W.W.; Newsted, P.R. Structural Equation Modeling analysis with Small Samples Using Partial Least Squares. In Statistical Strategies For Small Sample Research; Hoyle, R., Ed.; Sage Publications, Inc.: Thousand Oak, CA, USA, 1999; pp. 307-341. ISBN 978-0761908869.

96. Yarnold, J.K. The minimum expectation in $\mathrm{X} 2$ goodness of fit tests and the accuracy of approximations for the null distribution. J. Am. Stat. Assoc. 1970, 65, 864-886.

97. Fornell, C.; Larcker, D.F. Evaluating Structural Equation Models with Unobservable Variables and Measurement Error. J. Mark. Res. 1981, 18, 39-50. [CrossRef]

98. Wirtz, B.W.; Pistoia, A.; Ullrich, S.; Göttel, V. Business Models: Origin, Development and Future Research Perspectives. Long Range Plan. 2016, 49, 36-54. [CrossRef]

99. Statistical Office of the Republic of Slovenia. The Level of Digitalization in Enterprises with 10 and more Employees in 2018; Statistical Office of the Republic of Slovenia: Ljubljana, Slovenia, 2018.

100. Hanelt, A.; Hildebrandt, B.; Polier, J. Uncovering the Role of Is in Business Model Innovation-A Taxonomy-Driven Aproach To Structure the Field. In Proceedings of the European Conference on Information Systems, Münster, Germany, 26-29 May 2015. 
101. Barjak, F.; Es-Sadki, N.; Arundel, A. The effectiveness of policies for formal knowledge transfer from European universities and public research institutes to firms. Res. Eval. 2015, 24, 4-18. [CrossRef]

102. Florén, H.; Agostini, A. The Business Model Innovation Map a Framework for Analyzing Business Model Innovation. In Proceedings of the 24th International Conference of the International Association for Management of Technology, Cape Town, South Africa, 8-11 June 2015; pp. 2192-2207. 